\title{
Pengaruh Latihan Fartlek dan Cross Country Terhadap Vo2Max Atlet Futsal Universitas Teknokrat Indonesia
}

\author{
Aditya Gumantan', Eko Bagus Fahrizqi² \\ ${ }^{1}$ Universitas Teknokrat Indonesia, ${ }^{2}$ Universitas Teknokrat Indonesia
}

\begin{abstract}
Abstrak
Tujuan yang ingin dicapai pada penelitian ini adalah untuk mengetahui peningkatan $\mathrm{VO}_{2} \mathrm{max}$ melalui latihan fartlek dan cross country. Penelitian ini menggunakan metode eksperimen, Sampel dalam penelitian ini adalah atlet futsal Universitas Teknokrat Indonesia.Berdasarkan dari hasil penelitian di dapat bahwa latihan dengan menggunakan metode fartlek dan cross countrymemberikan pengaruh yang signifikan terhadap tingkat $\mathrm{Vo}_{2}$ max.Latihan dengan menggunakan metode fartlek memiliki pengaruh yang lebih besar terhadap tingkat $\mathrm{Vo}_{2} \mathrm{max}_{\text {, hal }}$ ini dapat dilihat dari hasil penghitungan data yang diperoleh. Hasil penelitian menunjukkan bahwa rata-rata $\mathrm{VO}_{2}$ max siswa pada tes akhir fartlekadalah 42,16 lebih besar dibandingkan dengan cross country dengan rata-rata $\mathrm{VO}_{2}$ max siswa 41,3.Kesimpulan dari penelitian ini adalah latihan dengan metode fartlek lebih efektif dibandingkan dengan latihan cross country terhadap tingkat $\mathrm{VO}_{2}$ max atlet futsal Universitas Teknokrat Indonesia.
\end{abstract}

Kata Kunci: cross country, fartlek, futsal, latihan, $\mathrm{VO}_{2} \max$

\begin{abstract}
The aim of this research was to determine the increase in $\mathrm{VO}_{2}$ Max through fartlek workout and cross country. This research used an experimental method, samples in this study were the futsal athletes in Universitas Teknokrat Indonesia. Based on the results of research in the can that exercises using fartlek and cross country have a significant influence on the level of $\mathrm{VO}_{2}$ max. Fartlek workout using the method has a greater influence on the level of $\mathrm{VO}_{2}$ max, this can be seen from the results of the calculation of the data obtained. The results showed that the average $\mathrm{VO}_{2}$ max students at the post test 42.16 fartlek is greater than the cross-country with an average of 41.3 students $\mathrm{VO}_{2} \mathrm{Max}$.

Keywords: cross country, Fartlek, futsal, exercise, $\mathrm{VO}_{2} \max$
\end{abstract}

\section{PENDAHULUAN}

Futsal merupakan olahraga sepak bola yang dimainkan di dalam ruangan. Menurut Halim (2009) futsal adalah permainan sejenis sepak bola yang dimainkan dalam lapangan yang berukuran lebih kecil.Futsal merupakan olahraga yang kompleks bukan hanya penguasaan teknik dasar yang baik saja tetapi faktor persiapan fisik juga sangat penting. Kondisi fisik yang baik akan mendukung performa yang ditampilkan pemain futsal di lapangan. Sehebat dan sebagus apapun teknik dan taktik pemain tanpa didasari kondisi fisik yang prima maka prestasi olahraga tidak akan tercapai dengan maksimal. Menurut Sofyan Hanif (2015) perlu diketahui komponen-komponen 
apa saja yang diperlukan untuk meningkatkan prestasi cabang olahraga yang ditekuni komponen komponen itu adalah daya tahan, kekuatan, kecepatan, kelincahan, power, keseimbangan, koordinasi, dan akurasi.

Menurut Lhaksana (2011) Futsal adalah olahraga yang kompleks karena memerlukan teknis dan taktis khusus. Begitu pula dalam kondisi hal fisik, pemain futsal memiliki perbedaan dengan kondisi fisik dengan olahraga lain. Karakteristik olahraga futsal adalah membutuhkan daya tahan kecepatan, daya tahan kekuatan dan kelincahan dalam waktu yang relatif lama.Futsal merupakan olahraga yang menuntut setiap pemainnya memiliki daya tahan aerobik atau Vozmax yang baik. Tinggi rendahnya daya tahan seseorang tergantung pada tinggi rendahnya kapasitas oksigen maksimal. Semakin baik Vo2Max seseorang maka akan semakin baik pula kondisi fisiknya.

Kemampuan aerobik (Vo2Max) adalah kemampuan olah daya aerobik terbesar yang dimiliki seseorang. Hal ini ditentukan oleh jumlah oksigen yang paling banyak dapat dipasok oleh jantung, pernapasan, dan hemo-hidro-limpatik atau transport $\mathrm{O}_{2}, \mathrm{CO}_{2}$ dan nutrisi pada setiap menit yang dimaksud denganVo2Max adalah derajat metabolisme aerob maksimum dalam aktivitas fisik dinamis yang dapat dicapai seseorang.

$\mathrm{VO}_{2}$ max dipengaruhi oleh beberapa faktor yaitu: genetik, jenis kelamin, usia, komposisi tubuh, aktifitas, dan latihan. Oleh karena itu, $\mathrm{VO}_{2} m a x$ dipakai sebagai parameter kesehatan dan alat ukur kekuatan aerobik maksimal dan kebugaran kardiorespirasi yangdimaksud denganVo2Maxadalah Dayatangkap aerobik maksimal menggambarkan jumlah oksigenmaksimumyang dikonsumsiper satuan waktu oleh seseorangselama latihan atau tes denganlatihanyangmakin lama makin berat sampai kelelahan, ukurannyadisebutVo2Max. Vo2Max adalah pengambilan oksigen (oxygenintake) selama upayamaksimal.

Untuk meningkatkan kapasitas vital paru latihan fisik harus dilakukan, peningkatan $\mathrm{VO}_{2}$ max sebaiknya dengan cara program latihan aerobic. Tinggi rendahnya $\mathrm{VO}_{2}$ max seseorang sangat berpengaruh pada kondisi fisik atau kesegaran jasmani pemain. Menurut Sukadiyanto (2011)“Peningkatan VO2max menjadi lebih tinggi mulai umur 10 tahun, walau ada yang berpendapat latihan ketahanan tidak terpengaruh 
pada kemampuan aerobik sebelum usia 11 tahun. Secara umum, kemampuan aerobik turun perlahan setelah usia 25 tahun".

Fartlek merupakan salah satu bentuk latihan untuk meningkatkan $\mathrm{VO}_{2} \mathrm{Max}$. menurut Sukadiyanto (2011) latihan fartlek merupakan suatu system daya tahan untuk membangun, mengembangkan, atau memelihara kondisi tubuh seorang atlet. Sedangkan menurut Lutan dkk, (2001) latihan fartlek sangat bagus efeknya terhadap pengembangan keterampilan teknik, kekuatan, daya tahan, dan kebugaran mental.

Metode latihan fartlek atau speed play yang diciptakan oleh Gosta Halmer, adalah suatu sistem pelatihan endurance, yang untuk membangun, mengembalikan, atau memelihara kondisi tubuh seseorang. Fartlek adalah kerja pada tingkat aerobik, yaitu dimana pemasukan (supply) oksigen yang masih cukup untuk memenuhi kebutuhan pekerjaan yang dilakukan oleh otot.

Latihan fartlek berdasarkan pada perubahan kelajuan dalam sesi latihan yaitu variasi fase lambat, sedang, dan cepat. Intensitas latihan yang dilakukan berada pada $60 \%$ - 80\% dari denyut jantung maksimal. Latihan fartlek memiliki tujuan untuk meningkatkan daya tahan paru. Cross country merupakan salah satu bentuk latihan yang digunakan untuk meningkatkan $\mathrm{VO}_{2}$ max. cross country dilaksanakan di alam terbuka. Untuk meningkat daya tahan, dapat melakukan variasi latihan dengan melakukan Cross Country, yaitu berlari dari tempat yang rendah ketempat yang lebih tinggi atau dapat di lakukan di alam bebas seperti di pemukimana dan perbukitan.

Lari lintas alam atau Cross Country merupakan salah satu lari jarak jauh yang di lakukan di alam terbuka, seperti jalan raya, pegunungan, pemukiman, atau hutan. Teknik lari lintas alam memiliki dasar yang sama dengan teknik lari jarak jauh. Menurut Irianto (2009) latihan lari secara teratur akan membuat paru-paru bekerja lebih efektif, jumlah masuknya oksigen yang bertambah ini membantu memudahkan kerja jantung. Cross Country adalah lari jarak jauh melintasi alam terbuka seperti pedesaan, pegunungan dan perbukitan. Cross Country merupakan jenis latihan daya tahan aerobik. 
Dapat di simpulkan dari beberapa pendapat para ahli di atas bahwa Cross Country (lari lintas alam) adalah lari jarak jauh di alam terbuka yang dilakukan sebagai salah satu bentuk latihan untuk meningkatkan $\mathrm{VO}_{2}$ max.

\section{METODE}

Penelitian ini menggunakan metode eksperimen yang bertujuan untuk mengetahui pengaruh suatu variabel bebas (treatment) terhadap variabel terikat dengan cara memanipulasi variabel bebas untuk kemudian melihat efeknya pada variabel terikat. Uhar Suharsaputra (2012) menjelaskan bahwa "metode eksperimen merupakan salah satu metode penelitian (inkuiri) dengan pendekatan kuantitatif yang dipandang paling kuat dalam mengkaji berbagai gejala yang ada khususnya berkaitan dengan hubungan pengaruh suatu faktor/variabel terhadap faktor/variabel lainnya.Dalam penelitian ini akan dideskripsikan mengenai besarnya pengaruh variabel bebas (treatment) latihan fartlek dan cross country terhadap variabel terikat $(\mathrm{Y})$ tingkat $\mathrm{VO}_{2} \mathrm{max}$.

\section{POPULASI DAN SAMPEL}

Populasi dan sampel dalam penelitian ini adalah mahasiswa yang mengikuti UKM Futsal Universitas Teknokrat Indonesia yang berjumlah 30 mahasiswa. Teknik sampling yang digunakan adalah total sampling yaitu, semua anggota populasi dijadikan sampel dalam penelitian ini.

\section{INSTRUMEN}

Teknik pengumpulan data dalam penelitian ini menggunakan tes bleep test. Data yang akan dikumpulkan dalam penelitian ini yaitu data Pre-test sebelum sampel diberikan perlakuan/treatment, dan data Post-test setelah sampel diberikan perlakuan/treatment.

\section{TEKNIK ANALISIS DATA}

Sebelum melangkah ke uji-t, ada persyaratan yang harus dipenuhi oleh peneliti bahwa data yang dianalisis harus berdistribusi normal, untuk itu perlu dilakukan uji normalitas Uji normalitas tidak lain sebenarnya adalah mengadakan pengujian terhadap normal tidaknya sebaran data yang akan dianalisis. Jika nilai $p>$ dari 0,05 maka data normal, akan tetapi sebaliknya jika hasil analisis menunjukkan nilai $p<$ dari 0,05 maka 
data tidak normal.Karena sampel dalam penelitian ini sudah homogen sehingga tidak perlu dilaksanakan uji homogenitas.

Terakhir melakukan uji t atau uji signifikasi. Dalam pengujian ini terdapat 2 tes uji signifikasi yaitu uji signifikasi peningkatan masing-masing kelompok (fartlek dan cross country) dengan menggunakan Paired Sample Test. Lalu uji signifikasi perbedaan peningkatan hasil kedua kelompok, dimana peneliti menggunakan Independent Sample t test yang bertujuan untuk mengetahui adakah perbedaan peningkatan yang signifikan dari hasil kedua kelompok.Pada bagian ini ungkapan secara jelas metode penelitian yang digunakan, didalamnya termasuk subjek penelitian, instrumen dan teknik analisis.

\section{HASIL DAN PEMBAHASAN}

Data yang diperoleh dari hasil tes maupun pengukuran masih belum berarti dan merupakan skor-skor mentah. Data-data yang terdapat dalam penelitian diolah dan dianalisis berdasarkan langkah-langkah penelitian yang telah diuraikan diatas. Adapun hasil dari pengolahan dan analisis data tersebut penulis uraikan pada tabel-tabel dibawah ini:

Tabel 1. Hasil Penghitungan Nilai Rata-rata dan simpangan baku kedua kelompok

\begin{tabular}{|c|c|c|c|}
\hline Kelompok & Periode Tes & $\bar{X}$ & Sd \\
\hline \multirow[t]{2}{*}{ Latihan fartlek } & Tes Awal & 35.8 & 0.950 \\
\hline & Tes Akhir & 42.1 & 0.975 \\
\hline \multirow[t]{2}{*}{ Latihan cross country } & Tes Awal & 35.8 & 0.968 \\
\hline & Tes Akhir & 41.3 & 0.987 \\
\hline
\end{tabular}

Dari tabel diatas menunjukkan bahwa rata-rata tes awal kelompok latihan fartlek sebesar 35.8 dengan simpangan baku 0.950 dan rata-rata latihan cross country sebesar 35.8 dengan simpangan baku sebesar 0,968. Sedangkan rata-rata tes akhir kelompok latihan fartlek sebesar 42.1 dengan simpangan baku sebesar 0.975 dan ratarata latihan cross country sebesar 41.4 dengan simpangan baku sebesar 0.987 . 


\section{Uji Normalitas}

Uji Normalitas data yang digunakan pada penelitian ini menggunakan uji liliefors dengan kriteria uji jika $\mathrm{L}$ hitung $<\mathrm{L}$ tabel, maka data tersebut berdistribusi normal. Berdasarkan hasil tes Vo2 Max pada kedua kelompok eksperimen dengan taraf signifikan 0,05 dan taraf kepercayaan 95\% memiliki nilai $L$ hitung yang lebih kecil daripada $L$ tabel, sehingga dapat disimpulkan bahwa distribusi data untuk semua variabel adalah normal. Berikut hasil uji normalitas data pada kelompok eksperimen 1 yaitu latihan cross country dan kelompok eksperimen 2 adalah latihan fartlek yang disajikan pada tabel berikut:

Tabel 2. Hasil Uji Normalitas

\begin{tabular}{llll}
\hline Data & $\mathbf{L}$ hitung & $\mathbf{L}$ tabel & Kesimpulan \\
\hline Data Tes Awal Fartlek & 0.152 & 0.220 & Normal \\
\hline Data Tes Awal Cross country & 0.149 & 0.220 & Normal \\
\hline Data Tes Akhir Fartlek & 0.127 & 0.220 & Normal \\
\hline Data Tes Akhir Cross country & 0.122 & 0.220 & Normal
\end{tabular}

Berdasarkan tabel di atas dapat diketahui bahwa data tes awal kelompok fartlek Lnitung $0,152<\mathrm{L}$ tabel 0,220 yang berarti data berdistribusi normal. Data tes awal kelompok cross country Lhitung $0,149<$ Ltabel 0,220 yang berarti data berdistribusi normal. Data tes akhir kelompok fartlek Lhitung $0,127<L$ tabel 0,220 yang berarti data berdistribusi normal dan data tes akhir kelompok cross country $L$ hitung $0,122<L$ tabel 0,220 yang berarti data berdistribusi normal.

\section{Uji Signifikan}

\section{Cross country}

Berdasarkan hasil uji normalitas pada kedua kelompok sampel baik tes awal maupun tes akhir maka dilakukan uji pengaruh untuk mengetahui pengaruh dan perbedaan perlakuan pada kedua kelompok sampel terhadap Vo2 Max atlet futsal dapat dilihat pada tabel berikut: 
Tabel 3. Hasil perhitungan uji pengaruh data pre test dan post test Latihan cross country

\begin{tabular}{|c|c|c|}
\hline \multirow[t]{2}{*}{ RATA-RATA } & Tes Awal & Tes Akhir \\
\hline & 35.8 & 41.3 \\
\hline SD & 0.968 & 0.98 \\
\hline $\mathbf{T}_{\text {hitung }}$ & & 69 \\
\hline $\mathbf{T}_{\text {tabel }}$ & & 45 \\
\hline
\end{tabular}

Nilai rata-rata VO2Max sebelum diberikan latihan cross country 35.8 dan nilai rata-rata VO2 Max setelah diberikan perlakuan latihan cross countryadalah 41.3 yang artinya bahwa terdapat peningkatan VO2Max dari tes awal dan tes akhir sehingga VO2Max atlet futsal Universitas Teknokrat Indonesia.

Berdasarkan hasil perhitungan uji pengaruh diperoleh nilai $t$ hitung 22,69 $>\mathrm{t}$ tabel 2,145 untuk a $5 \%$ dengan $\mathrm{dk}=14$, yang berarti ada pengaruh data hasil pre test dan data hasil post test kelompok latihan cross country, dengan demikian dapat disimpulkan bahwa ada pengaruh yang signifikan dari latihan cross countryterhadap Vo2 Maxatlet futsal Universitas Teknokrat Indonesia.

\section{Fartlek}

Berdasarkan hasil uji normalitas pada kedua kelompok sampel baik tes awal maupun tes akhir maka dilakukan uji pengaruh dan uji t untuk mengetahui pengaruh dan perbedaan perlakuan pada kedua kelompok sampel terhadap Vo2 Max dapat dilihat pada tabel berikut:

Uji Pengaruh data pre test dan post test kelompok fartlek dilakukan untuk mengetahui berpengaruh atau tidaknya latihan fartlek terhadap Vo2 Max. Hasil perhitungan uji pengaruh pada data pre test dan post test dapat dilihat pada tabel di berikut ini:

Tabel 3. Hasil perhitungan uji pengaruh data pre test dan post test Latihan Fartlek

\begin{tabular}{ccc} 
RATA-RATA & Tes Awal & Tes Akhir \\
\cline { 2 - 3 } & 35.8 & 42.16
\end{tabular}




\begin{tabular}{|c|c|c|}
\hline SD & 0.95 & 0.97 \\
\hline $\mathbf{T}_{\text {hitung }}$ & & \\
\hline $\mathbf{T}_{\text {tabel }}$ & & \\
\hline
\end{tabular}

Nilai rata-rata VO2Max sebelum diberikan latihan fartlek35.8 dan rata-rata VO2 Max setelah diberikan perlakuan latihan fartlekadalah 42.16 yang artinya bahwa terdapat peningkatan VO2 Max dari tes awal dan tes akhir sehingga VO2 Max meningkat.

Berdasarkan hasil perhitungan uji pengaruh diperoleh nilai $t$ hitung $25,94>t$ tabel 2,145 untuk a $5 \%$ dengan $\mathrm{dk}=14$, yang berarti ada pengaruh data hasil pre test dan data hasil post test kelompok latihan fartlek, dengan demikian dapat disimpulkan bahwa ada pengaruh yang signifikan dari latihan fartlek terhadap Vo2 Maxatlet futsal Universitas Teknokrat Indonesia.

Dari hasil pengolahan data dihasilkan bahwa tingkat VO2 Max yang diperoleh menggunakan metode latihan Cross Country adalah 41.3 yang berada pada level baik menurut norma bleep test untuk klasifikasi umur 20-29 dan fartlek adalah 42.16 yang berada pada level baik menurut norma bleep testyang artinya bahwa ada peningkatan yang signifikan dengan menggunakan latihan fartlek.

\section{KESIMPULAN}

Berdasarkan hasil analisis data, hasil pengujian hipotesis dan pembahasan penelitian yang telah diperoleh maka dapat dijelaskan beberapa kesimpulan sebagai berikut: 1) Terdapat pengaruh latihan fartlekterhadapVO2Maxatlet futsal Universitas Teknokrat Indonesia. 2)Terdapat pengaruh cross countryterhadapVO2Maxatlet futsal Universitas Teknokrat Indonesia.3)Terdapat perbedaan pengaruh fartlekdan cross countryterhadapVO2Maxatlet futsal Universitas Teknokrat Indonesia. Darihasilpenelitian diperolehbahwafartlekmemilikihasilyanglebih baik dari cross countrydalampeningkatan VO2Maxatlet futsal Universitas Teknokrat Indonesia. 


\section{DAFTAR PUSTAKA}

Halim, Sahda. (2009). 1 Hari Pintar Main Futsal. Jakarta: Media Persindo.

Hanif, Achmad S. (2015).Kepelatihan Dasar Sepak Takraw. Jakarta: Raja Grafindo Persada.

Irianto, Djoko P. (2009). Pelatihan Kondisi Fisik Dasar. Jakarta: SDEP Pengembangan Tenaga dan Pembinaan Keolahragaan.

Lhaksana, Justinus. (2011).Teknik dan Strategi Futsal Modern. Jakarta: Be Champion.

Rusli Lutan, dkk. (2001). Pendidikan Kebugaran Jasmani. Jakarta: Direktorat Jendral Olahraga.

Suharsaputra, Uhar. 2012. MetodePenelitianKuantitatif, Kualitatif, danTindakan.Bandung: PT Refika Aditama.

Sukadiyanto. (2011). Pengantar teori dan metodologi melatih fisik. Bandung: Lubuk Agung. 